\title{
Hubungan Antara Keterlibatan Kerja Dengan Organizational Citizenship Behavior (OCB) Pada Karyawan Yang Menggunakan Komputer Di PT Semen Baturaja (Persero) Palembang
}

\author{
Rina Oktaviana \\ Universitas Bina Darma \\ Email: rina.oktaviana@binadarma.ac.id
}

\begin{abstract}
This study aims to determine the relationship between job involvement with organizational citizenship behavior (ocb) on employees. who use computers at PT. Semen Baturaja (Persero) Palembang. The dependent variable in this study is Organizational Citizenship Behavior (OCB) while Job Involvement as independent variable. This study uses the scale of Organizational Citizenship Behavior (OCB) and Job Involvement. This research uses quantitative method. The sample in this study as many as 146 employees of PT. Semen Baturaja (Persero) Tbk Palembang and data were analyzed using simple regression technique.
\end{abstract} Keywords: Organizational Citizenship Behavior (OCB) and Job Involvement

Abstrak

Penelitian ini bertujuan untuk mengetahui hubungan antara keterlibatan kerja dengan Organizational Citizenship Behaviour (OCB) pada karyawan yang menggunakan komputer di PT. Semen Baturaja (Persero) Palembang. Variabel terikat dalam penelitian ini adalah Organizational Citizenship Behaviour (ocb) sementara keterlibatan kerja sebagai variabel bebas. Penelitian ini menggunakan skala organizational citizenship behaviour (ocb) dan keterlibatan kerja. Penelitian ini menggunakan metode kuantitatif. Sampel dalam penelitian ini sebanyak 146 karyawan PT. Semen Baturaja (Persero) Tbk Palembang dan data dianalisis menggunakan teknik regresi sederhana.Hasil dari penelitian ini menunjukkan adanya hubungan yang sangat signifikan antara keterlibatan kerja dengan organizational citizenship behaviour (ocb) pada karyawan yang menggunakan komputer di PT. Semen Baturaja (Persero) Palembang.

Kata kunci: Organizational Citizenship Behaviour (OCB) dan Keterlibatan Kerja

\section{Pendahuluan}

Sumber daya manusia merupakan pondasi dari organisasi serta merupakan hal yang tidak dapat diabaikan. Sebagai pondasi utama, sumber daya manusia menjadi faktor yang sangat berperan dalam mencapai tujuan organisasi. Sumber daya manusia merupakan sumber daya yang digunakan untuk mendukung sumber daya lainnya agar mencapai tujuan organisasi (Kartini, 2013). Organisasi yang sukses membutuhkan karyawan yang akan melakukan lebih dari sekedar tugas formal mereka dan mau memberikan kinerja yang melebihi harapan. PT. Semen Baturaja (Persero) Tbk merupakan salah satu perusahaan BUMN yang bergerak di industri semen di wilayah Sumatera Bagian Selatan telah melakukan berbagai usaha untuk meningkatkan kualitas dan profesionalisme karyawan sesuai tuntutan budaya kerja perusahaan yaitu JUMP FOR WIN dimana karyawan diharapkan Jujur, Kompeten, Profesional, Kerjasama, Tanggung Jawab dan Peduli. Tuntutan budaya kerja perusahaan pada karyawan tersebut salah satunya yaitu peduli, dengan peduli seorang karyawan akan disiplin, mau membantu serta terlibat aktif dan sukarela memberikan yang terbaik untuk sesama karyawan dan perusahaan

Johns mengemukakan bahwa Organizational Citizenship Behaviour (selanjutnya disingkat OCB) adalah perilaku sukarela yang tidak ada dalam uraian jabatan. Perilaku 


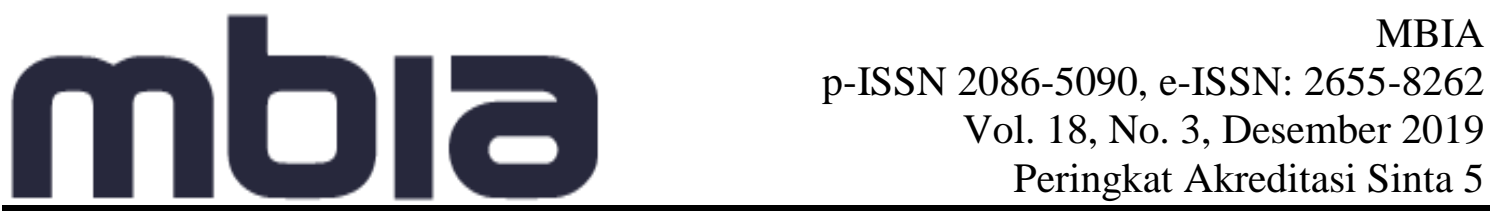

spontan karyawan tanpa saran atau perintah seseorang sehingga bersifat menolong (Budihardjo, Kristamuljana, Sidik, Simandjuntak, Soehadi, Wintoro, 2011).

Wirawan (2014) menjelaskan bahwa keterlibatan kerja merupakan salah satu faktor yang signifikan dalam menciptakan Organizational Citizenship Behavior (OCB). Keterlibatan kerja yaitu derajat dimana orang dikenal dari pekerjaannya, berpartisipasi aktif didalamnya, dan menganggap prestasinya penting untuk harga diri.

Perkembangan dunia iptek yang demikian pesat telah membawa manfaat luar biasa bagi kemajuan perusahaan. Jenis-jenis pekerjaan yang sebelumnya menuntut kemampuan fisik cukup besar, kini sudah bisa digantikan dengan perangkat mesin otomatis, salah satunya komputer. Komputer telah banyak membantu karyawan dalam proses memajukan perusahaan. Komputer adalah seperangkat alat elektronik yang dihubungkan dengan listrik yang berguna untuk membantu pekerjaan manusia agar lebih mudah, cepat, dan akurat (Yani, 2008). Fungsi dan kegunaan komputer diantaranya melakukan sistem pemrograman dan pemrosesan data, Khususnya pada karyawan PT. Semen Baturaja (Persero) dimana dalam perusahaan ini memiliki biro atau bagian-bagian dengan tugas dan tanggung jawab masing-masing. Biro Sumber Daya Manusia (selanjutnya disingkat SDM) tugas dan tanggung jawab meliputi, tinjauan organisasi, pembinaan dan pengembangan SDM, serta pemeliharaan SDM. Karyawan bagian SDM memiliki fasilitas komputer pada tiap meja kerja sebagai alat bantu dalam mengerjakan tugas.

Permasalahan yang terjadi pada karyawan PT. Semen Baturaja (Persero) Palembang terkait perilaku OCB sebanyak 9\% karyawan menunjukkan tidak bisa menahan diri dari aktivitas mengeluh dan menggerutu karena pekerjaan yang dikerjakan tidak sesuai job desc-nya. Tidak adanya reward untuk setiap tugas lain diluar job desc saat karyawan dapat mengerjakannya dengan baik. Sebanyak 10,2\% karyawan menunjukkan tidak mau menolong rekan kerja yang sedang kesulitan dalam pekerjaannya dengan alasan sudah ada job desc-nya masing-masing, lebih pilih tugas sendiri daripada menolong orang lain, dan harus profesional. Sebanyak 11,6\% karyawan menunjukkan tidak mau menggantikan rekan kerja yang tidak masuk dengan alasan karyawan harus profesional, tidak ada waktu untuk menggantikan, dan sibuk dengan pekerjaan sendiri. Sebanyak $8,8 \%$ karyawan menunjukkan tidak tepat waktu dengan alasan macetnya lalu lintas, mengantar anak ke sekolah, serta bangun kesiangan karena begadang. Sebanyak 9,2\% karyawan menunjukkan tidak mengikuti pengumuman organisasi dimana dalam peraturan tersebut menyatakan larangan untuk bermain game online pada waktu jam kerja. Dari hasil penyebaran angket awal diatas dapat disimpulkan bahwa 48,8\% menunjukkan rendahnya perilaku OCB pada karyawan PT. Semen Baturaja (Persero) Palembang Tbk.

Permasalahan keterlibatan Kerja karyawan PT. Semen Baturaja (Persero) Palembang, sebanyak $8,2 \%$ karyawan melakukan sedikit usaha untuk kemajuan perusahaan dengan alasan adanya diskriminasi dari atasan pada karyawan yang merupakan bagian dari keluarganya, tidak mau datang ke kantor karena pekerjaan mendadak yang mengharuskan karyawan datang pada jam subuh. Sebanyak $12 \%$ karyawan menunjukkan tidak puas dengan pekerjaan yang dijalaninya sekarang karena penempatan yang dijalaninya tidak sesuai dengan jurusan ditempat kuliah dulu. Sebanyak 9,2\% karyawan menunjukkan tidak memiliki komitmen terhadap pekerjan dengan alasan ada diskriminasi dari pihak 
atasan terhadap karyawan lain. Sebanyak $10,4 \%$ karyawan menunjukkan tidak peduli dengan pekerjaan karena karyawan tidak mendapatkan reward saat mampu mengerjakan tugas diluar pekerjaannya. Sebanyak 9,8\% karyawan menunjukkan rendahnya motivasi pada pekerjaan yang dijalani. Dari hasil penyebaran angket awal diatas dapat disimpulkan 49,6\% karyawan menunjukkan rendahnya keterlibatan kerja pada karyawan PT. Semen Baturaja (Persero) Palembang Tbk.

\section{Literature Review}

Organizational Citizenship Behaviour (OCB) merupakan perilaku karyawan yang dilakukannya secara sukarela, tidak berhubungan langsung maupun tidak langsung dengan sistem imbalan, dan secara keseluruhan perilaku tersebut mendukung efektivitas dan efisiensi organisasi (Organ, 2006).

dimensi-dimensi Organizational Citizenship Behaviour (OCB) menurut Organ (Hoffman, 2007) yaitu Aultruisme, Courtesy, Civic Virtue, Conscientiousness, Sportmanship

Menurut Aldag dan Resckhe, (1997) karakteristik dari perilaku OCB berupa 1. perilaku menolong rekan kerja yang sedang kesulitan dalam pekerjaannya, 2. menggantikan rekan kerja yang tidak masuk atau istirahat, 3. membantu rekan sejawat yang pekerjaannya overloud, 4 . membantu mengerjakan tugas orang lain pada saat tidak masuk, 5. membantu orang lain di luar departemen ketika memiliki permasalahan, 6. tepat waktu setiap hari tidak peduli pada musim ataupun lalu lintas, 7. membantu proses orientasi karyawan baru meskipun tidak diminta, 8. Tidak menghabiskan waktu untuk pembicaraan di luar pekerjaan, 9. kemauan untuk bertoleransi tanpa mengeluh, 10. menahan diri dari aktivitas-aktivitas mengeluh dan mengumpat, 11. memberikan perhatian terhadap pertemuan-pertemuan yang dianggap penting, 12. membuat pertimbangan dalam menilai apa yang terbaik untuk organisasi, 13. membaca dan mengikuti pengumuman organisasi (Sofyandi, 2007).

Hiriyappa (2009) mendefinisikan keterlibatan kerja sebagai tingkat sampai sejauh mana individu mengidentifikasikan dirinya dengan pekerjaannya, secara aktif berpartisipasi di dalamnya, dan menganggap performansi yang dilakukannya penting.

Dimensi-dimensi keterlibatan kerja dari Saleh dan Hoseck (Luthans, 2006) yaitu pekerjaan adalah minat hidup yang utama, partisipasi aktif dalam pekerjaan, menganggap performa sebagai hal penting bagi dirinya, mengganggap kinerja konsisten dengan konsep dirinya.

Karakteristik dari karyawan yang memiliki keterlibatan kerja yang tinggi dan yang rendah menurut Cohen (2003). Keterlibatan kerja yang tinggi antara lain menghabiskan waktu untuk bekerja, memiliki kepedulian yang tinggi terhadap pekerjaan dan perusahaan, puas dengan pekerjaannya, memiliki komitmen yang tinggi terhadap karier, profesi, dan organisasi. Memberikan usaha-usaha yang terbaik untuk perusahaan, tingkat absen dan intensi turnover rendah, memiliki motivasi yang tinggi. 
Keterlibatan kerja yang rendah antara lain tidak mau berusaha keras untuk kemajuan perusahaan, tidak peduli dengan pekerjaan maupun perusahaan, tidak puas dengan pekerjaan, tidak memiliki komitmen terhadap pekerjaan maupun perusahaan. Tingkat absen dan intensi turnover tinggi, memiliki motivasi kerja yang rendah, tingkat pengunduran diri yang tinggi, merasa kurang bangga dengan pekerjaan dan perusahaan.

Penelitian dari luar juga pernah dilakukan oleh Noe, Asil, Doostar, Karimi pada tahun 2013 dengan judul Mempelajari Hubungan antara Keterlibatan Kerja dan Komitmen Organisasi dengan Organizational Citizenship Behaviour (OCB) dalam Pengelolaan Haji di Provinsi Timur Azerbaijan. Hasil menunjukkan bahwa ada korelasi yang kuat dengan variabel prediktor (keterlibatan kerja dan komitmen organisasi) dengan variabel kriteria (OCB). Penelitian yang sama dilakukan oleh Swagaretha, Winarno, Juariyah dengan judul Pengaruh Kepuasan Kerja dan Keterlibatan Kerja terhadap Organizational Citizenship Behaviour (OCB) Karyawan PT. Telekomunikasi Indonesia, Tbk. Witel Jatim Selatan Malang pada tahun 2016. Hasil penelitian menunjukkan tingkat kepuasan kerja dan OCB karyawan dalam kategori sangat tinggi dan tingkat keterlibatan kerja kategori tinggi. Kepuasan kerja berpengaruh secara positif dan signifikan terhadap OCB karyawan. Keterlibatan kerja berpengaruh secara positif dan signifikan terhadap OCB karyawan.

\section{Metodologi Penelitian}

Lokasi Penelitian ini dilakukan pada PT Semen Baturaja (Persero) Tbk yang beralamat di jalan abi kusno cokro suyoso, kertapati kota palembang Sumatera Selatan. Variabel dalam penelitian ini adalah variabel keterlibatan kerja dan variabel organizational citizenship behaviour $(O C B)$, Dalam penelitian ini yang menjadi populasi adalah seluruh karyawan PT. Semen baturaja Palembang aktif menggunakan komputer berjumlah 146 orang. Dengan menggunakan rumus Isaac dan Michael dengan taraf kesalahan 10\%, maka ukuran sampel adalah sebanyak 146 responden. Teknik pengumpulan data yang digunakan dalam penelitian ini adalah skala yang berhubungan dengan dimensi-dimensi yang digunakan. Teknik Analisis menggunakan regresi sederhana.

\section{Hasil dan Pembahasan}

Tabel 1. Hasil Uji Normalitas

\begin{tabular}{cccc}
\hline Variabel & KS-Z & P & Keterangan \\
\hline $\begin{array}{c}\text { Organizational } \\
\text { Citizenship Behaviour }\end{array}$ & 1,123 & 0,160 & Normal \\
\hline Keterlibatan Kerja & 1,303 & 0,067 & Normal \\
\hline
\end{tabular}

Keterangan : KS-Z = Uji Kolmogorov Smirnov

$\mathrm{p}=$ Signifikasi 
Tabel 2. Hasil Uji Linieritas antara Keterlibatan Kerja dengan Organizational Citizenship Behaviour pada karyawan yang menggunakan komputer

\begin{tabular}{lccc}
\hline Variabel & F & P & Keterangan \\
\hline $\begin{array}{c}\text { Keterlibatan Kerja (X) dengan } \\
\text { Organizational Citizenship } \\
\text { Behaviour (Y) }\end{array}$ & 32,395 & 0,000 & Linier \\
\hline
\end{tabular}

Tabel 3. Hasil Uji Regresi Sederhana

\begin{tabular}{cccccc}
\hline Variabel & R & $\mathbf{R}^{\mathbf{2}}$ & F & P & Keterangan \\
\hline $\begin{array}{c}\text { Keterlibatan Kerja (X) } \\
\text { dengan Organizational } \\
\begin{array}{c}\text { Citizenship Behaviour } \\
\text { (Y) }\end{array}\end{array}$ & 0,429 & 0,184 & 32,395 & 0,000 & Sangat \\
Signifikan \\
\hline
\end{tabular}

Berdasarkan hasil uji tabel diatas, terlihat bahwa kedua data yang diperoleh melalui alat ukur yang dibuat oleh peneliti berdistribusi normal karena memenuhi syarat kaidah $\mathrm{p}>$ 0,05 dapat dilihat dari nilai $\mathrm{p}$ alat ukur tersebut yaitu pada Organizational Citizenship Behaviour $(1,123)$ dan Keterlibatan Kerja $(0,067)$ yang lebih besar dari 0,05. Selanjutnya untuk tabel data uji linieritas antara Keterlibatan Kerja dengan Organizational Citizenship Behaviour pada karyawan yang menggunakan komputer dapat dilihat bahwa terdapat hubungan yang linier karena memenuhi kaidah $\mathrm{p}<0,01$. Hasil tersebut dapat dilihat dari nilai $\mathrm{p}(0,000)$ yang lebih kecil dari 0,01 . Hasil Berdasarkan tabel diatas, diperoleh hasil nilai korelasi antara variabel Keterlibatan Kerja dengan Organizational Citizenship Behaviourpada karyawan yang menggunakan komputer yaitu $\mathrm{r}=0,429$ dengan nilai $\mathrm{F}=$ 32,395 dan $p=0,000$ dimana $p<0,01$. Ini berarti ada hubungan yang sangat signifikan antara Keterlibatan Kerja dengan Organizational Citizenship Behaviour pada karyawan yang menggunakan komputer di PT. Semen Baturaja (Persero) Palembang. Kemudian, besarnya sumbangan efektif yang diberikan oleh variabel Keterlibatan Kerja dengan Organizational Citizenship Behaviour pada karyawan yang menggunakan komputer adalah sebesar 0,184 atau $18,4 \%$. Jadi masih terdapat $81,6 \%$ pengaruh dari faktor-faktor lain yang berhubungan dengan Organizational Citizenship Behaviour.

Penelitian yang dilakukan mengenai Keterlibatan Kerja dengan Organizational Citizenship Behaviour pada karyawan yang menggunakan komputer ini menggunakan regresi sederhana yang bertujuan untuk menguji hipotesis tentang adanya hubungan antara Keterlibatan Kerja dengan Organizational Citizenship Behaviour pada karyawan yang menggunakan komputer di PT. Semen Baturaja (Persero) Palembang. Hasil analisis yang diperoleh dari penelitian ini adalah adanya penerimaan pada hipotesis yang diajukan. Hasil tersebut dapat dilihat dari nilai koefisien korelasi $r=0,429$ dengan nilai signifikansi $(\mathrm{p})=0,000$ atau dengan kata lain $\mathrm{p}<0,01$. Ini menunjukan bahwa ada hubungan yang sangat signifikan antara Keterlibatan Kerja dengan Organizational Citizenship Behaviour pada karyawan yang menggunakan komputer di PT. Semen Baturaja (Persero) Palembang.

Hubungan ini juga didukung oleh Saputra, Yono, dan Irvianti (2013) yang menyatakan bahwa keterlibatan kerja berpengaruh secara positif dan signifikan, dan memiliki 


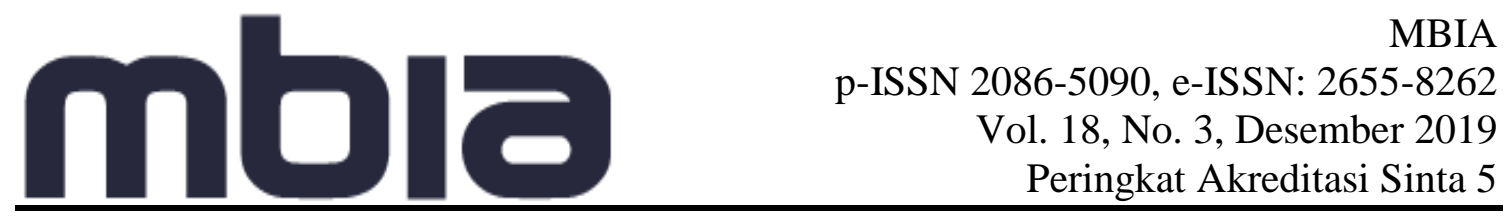

pengaruh yang sangat tinggi terhadap OCB. Penjelasan di atas sesuai dengan hasil penelitian yang menunjukkan bahwa karyawan PT. Semen Baturaja (Persero) Palembang menghadiri pertemuan unit saat dibutuhkan, terlibat dalam pengambilan keputusan saat rapat dengan cara aktif mengemukakan ide/gagasan mengenai perusahaan. Karyawan ikut serta dalam kegiatan kantor, seperti mengikuti seminar yang diadakan perusahaan. Karyawan bekerja sama dengan rekan kerja saat menyelesaikan masalah, menghindari konflik dengan rekan kerja serta meluangkan waktu untuk mendengarkan masalah orang lain.

Besarnya nilai sumbangan yang diberikan variabel Keterlibatan Kerja dengan Organizational Citizenship Behaviour adalah sebesar 0,184 atau 18,4\% sedangkan sisanya $81,6 \%$ masih dipengaruhi oleh faktor-faktor lain yang berhubungan dengan Organizational Citizenship Behaviour tetapi variabel itu tidak di diteliti oleh peneliti. Faktor-faktor lain itu diantaranya karakteristik individual, karakteristik tugas/pekerjaan, karakteristik organisasional dan perilaku pemimpin. Karakteristik individu merupakan perbedaan dari masing-masing individu yang akan mempengaruhi dalam perilaku kerja,Podsakoff (Garay, 2006). Sehingga untuk keterlibatan kerja terlihat sedikit pengaruhnya seperti yang terlihat pada hasil analisis data, yaitu sebesar 18,4\%.

Dari hasil penelitian, terlihat karyawan PT. Semen Baturaja (Persero) Palembang menganggap pekerjaan sebagai bagian dari hidup, karena melalui pekerjaan yang dijalani karyawan mendapat pengalaman positif dari pekerjaannya tersebut. Karyawan membuat pertimbangan untuk menilai yang terbaik buat perusahaan, mengerjakan tugas tanpa mengeluh dan tanpa mengharapkan imbalan. Karyawan mengikuti perkembangan organisasi, meningkatkan motivasi kerja dengan mengikuti seminar dan pelatihan yang diberikan perusahaan. Karyawan juga memperoleh dukungan dari atasan untuk menyelesaikan tugas tepat waktu. Brown (Muchinsky, 2003) mengatakan bahwa keterlibatan kerja merujuk pada tingkat dimana seseorang secara psikologis memihak kepada organisasinya dan pentingnya pekerjaan bagi gambaran dirinya.

Penelitian lainnya juga pernah dilakukan oleh Kimbal, Sendow, dan Adare dengan Judul Beban Kerja, Organizational Citizenship Behaviour, dan Keterlibatan Kerja pengaruhnya terhadap Kinerja Karyawan PT. PLN (Persero) Wilayah Suluttenggo Area Manado pada tahun 2015. Hasil penelitian menunjukan secara simultan beban kerja, Organizational Citizenship Behaviour, dan keterlibatan kerja berpengaruh terhadap kinerja karyawan. Lebih lanjut, beban kerja tidak berpengaruh terhadap kinerja karyawan, namun Organizational Citizenship Behaviour dan keterlibatan kerja berpengaruh positif terhadap kinerja karyawan.

Penelitian luar lainnya juga pernah dilakukan oleh Nwibere dengan judul Hubungan Interaktif antara Keterlibatan Kerja, Kepuasan Kerja, Organizational Citizenship Behaviour (OCB), dan Komitmen Organisasi di Universitas Nigeria Tahun 2014. Temuan mengungkapkan bahwa keterlibatan kerja memiliki hubungan yang positif dan signifikan yang kuat dengan komitmen organisasi dan OCB. Demikian pula, kepuasan kerja terungkap memiliki hubungan positif dan signifikan dengan komitmen organisasi dan OCB. Akhirnya, komitmen organisasi terungkap memiliki hubungan positif dan signifikan dengan OCB. 


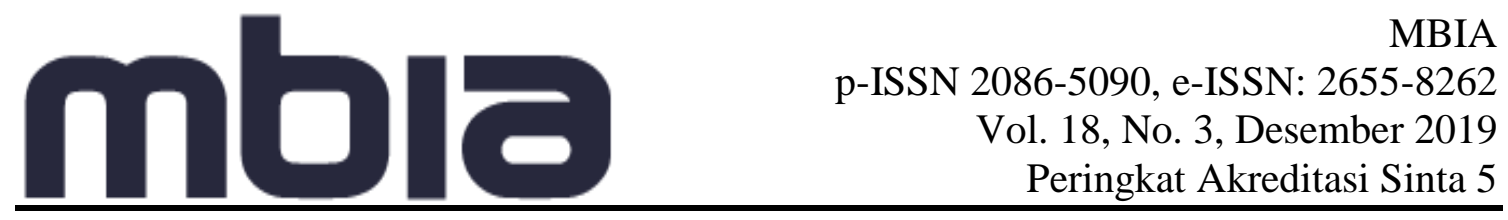

Penelitian selanjutnya penelitian dari luar yang sama yaitu penelitian oleh Ueda Yutaka tahun 2012 dengan judul Pengaruh Keterlibatan Kerja serta pentingnya evaluasi Organizational Citizenship Behaviour (OCB). Hasil penelitian menunjukkan bahwa sementara keterlibatan afektif dan perilaku memiliki efek positif secara signifikan pada evaluasi beberapa dimensi OCB, kognitif.

Penelitian lainnya yaitu penelitian oleh Saxena dengan judul Dampak Keterlibatan Kerja dan Komitmen Organisasi pada Organizational Citizenship Behavior (OCB) tahun 2014. Hasil penelitian menunjukkan bahwa ada dampak yang signifikan dari variabel independen terhadap variabel dependen, yaitu, ada dampak yang signifikan keterlibatan kerja dan komitmen organisasi pada OCB.

\section{Simpulan}

Bagi PT. Semen Baturaja (Persero) Palembang, penelitian ini diharapkan bisa menjadi gambaran untuk dapat meningkatkan motivasi kerja karyawan dengan mengadakan seminar dan pelatihan yang bermanfaat untuk karyawan, memberikan dukungan pada karyawan untuk dapat menyelesaikan tugas dengan baik, bertindak adil dengan memberikan gaji yang sesuai dengan beban kerja karyawan. Dengan adanya keterlibatan kerja yang baik antar karyawan akan memunculkan karakteristik individu yang menganggap pekerjaan sebagai bagian penting dalam hidup, serta karyawan akan mendapatkan pengalaman positif dari pekerjaan yang dijalani.

\section{Daftar Pustaka}

Aldag, R., and Reschke, W. (1997). Employee Value Added: Measuring Discretionary Effort and Its Value. Center fo $r \mathrm{O} r \mathrm{~g}$ a $n \mathrm{i}$ z a $t$ i o $n$ Effectiveness, 1-8.

Budihardjo, A., Kristamuljana, S., Sidik, I., Simandjutak, D., Soehadi, A. \& Wintoro, D. (2011). Pijar-Pijar Manajemen Bisnis Indonesia. Jakarta : Prasetya Mulya Publishing. Cetakan 1.

Cohen, A. \& E. Vigoda. (2003). Do Good Citizen Make Good Organizaional Citizens Administration and Society. Vol 32, 596-624.

Hoffman. (2007). Expanding the Criterion Domain? A Quantitative Review of the OCB Literature. Journal Of Applied Psychology, 92, 555-556.

Kartini, L. (2013). Organizational Citizenship Behavior (OCB) dan Komitmen Organisasi pengaruhnya terhadap Kinerja Karyawan. Jurnal EMBA, Vol. 1 No. 4 Desember 2013, Hal. 782-790.

Kimbal, F., Sendow, G. \& Adare, D. (2015). Beban Kerja, Organizational Citizenship Behavior (OCB), dan Keterlibatan Kerja Pengaruhnya terhadap Kinerja Karyawan PT. PLN (Persero) Wilayah Suluttenggo Area Manado. Jurnal EMBA Vol. 3 No. 2 Juni 2015, Hal. 1061-1072.

Luthans, F. (2006). Alih Bahasa : Vivin Andhika Yuwono; Shekar Purwanti, Perilaku Organisasi Edisi Sepuluh. Yogyakarta: ANDI.

Muchinsky, M., P. (2003). Psychology Applied to Work, Ed 4. California: Brooks/Cole Publishing Company Pacific Grove.

Noe., Dostar, M. \& Karimi, K. (2013). Studying The Relationship Between Job Involvement and Organizational Citizenship Behavior in Management of The Hajj Pilgrimage in East Azerbaijan Province. TJEAS Journal-2013-3-18/2178-2183. 


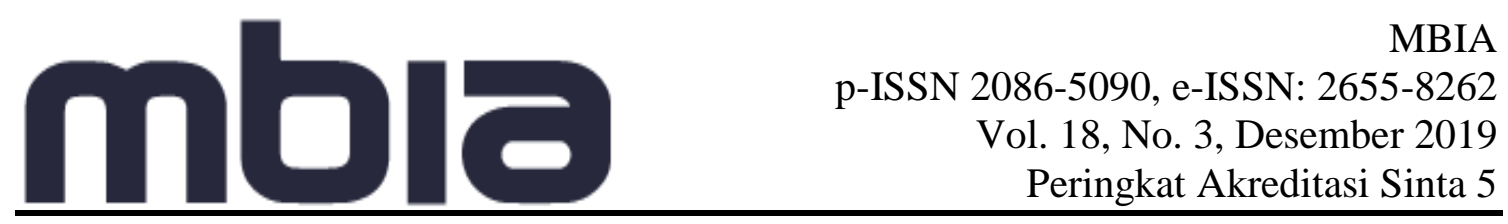

Nwibere, B. M. (2014). Interactive Relationship Between Job Involvement, Job Satisfaction, Organizational Citizenship Behavior, and Organizational Commitment in Nigerian Universities. International Journal of Management and Sustainabillity, 2014, 3(6): 321-340.

Organ, D. W., Podsakoff \& Mackenzie. (2006). Organizational Citizenship Behavior. Its Nature, Antecendents, and Consequences. California: Sage Publications, Inc.

Saputra, A., Yono, L. H. \& Irvianti, L.S. (2013). Analisis Pengaruh Keterlibatan Kerja dan Kepuasan Kerja terhadap Organizational Citizenship Behavior di PT. Prima Graphia Digital. Jurnal Binus Business Review, Vol. 4 No. 2 November 2013. 897903.

Sofyandi, H. (2007). Manajemen Sumber Daya Manusia. Yogyakarta: Graha Ilmu

Saxena, S. \& Saxena, R. (2014). Impact of Job Involvement and Organizational Commitment on Organizational Citizenship Behavior. International Journal of Management and Business, 5(1), 19-30, Winter 2015.

Swagaretha, Y., Winarno, A. \& Juariyah, L. (2016). Pengaruh Kepuasan Kerja dan Keterlibatan Kerja Terhadap Organizational Citizenship Behavior (OCB) Karyawan PT. Telekomunikasi Indonesia, Tbk. Witel Jatim Selatan Malang. Jurnal Ekonomi Bisnis Tahun 21, Nomor 2, Oktober 2016.

Ueda, Y. (2012). Effect of Job Involvement on Importance Evaluation of Organizational Citizenship Behavior. International Journal of Business and Society, Vol. 13 No. 1, 2012, 77-89.

Wirawan. (2014). Kepemimpinan : Teori, Psikologi, Perilaku Organisasi, Aplikasi dan P e n e l i t i a $n$. J a k a r t a : Raja Grafindo Persada.

Yani, A. (2008). Panduan Menjadi Teknisi Komputer. Jakarta: Kawan Pustaka. Cetakan Ketigabelas

\section{Copyright Disclaimer}

Copyright for this article is retained by the author(s), with first publication rights granted to the journal. 